\title{
The Influence of Learning Strategy in a Series of Games for Kindergarten Students
}

\author{
Willadi Rasyid, Zainul Johor, Heru Afrian*, Arie Asnaldi, Oktarifaldi, Syahrial Bakhtiar \\ Faculty of Sport Science \\ Padang State University \\ Padang, Indonesia \\ *heruafrian14@gmail.com
}

\begin{abstract}
This study aims to reveal the effect of learning strategies on conventional and game chains on the ability of object control students in TK Pembina Padang Panjang. This research used a quasi-experiment design that involved 40 students aged 5 to 6 years. Object control capability data is obtained by giving the TGMD-2 test. Data were analyzed using a two-way variant analysis (ANOVA) technique with a $2 \times 2$ factorial design. The results show that: 1) There is a difference in the ability of fundamental movement skills between groups of children who are given a strategy of learning a series of conventional games with a value of $Q$ 3.61 > Qtable 2.95). 2) There is a difference in Basic Motion Skills between a child who has a normal BMI and a child who has a lean/fat BMI Q count 3.61> Qtable 2.95. 3) There is an interaction between learning strategies with the level of BMI towards the mastery of basic child movement skills shown with a value of $0.000<0.05$. 4) There is a difference in the ability of basic child movement skills between groups who have an average BMI given SPRP with conventional learning strategies with the calculation of the value of $Q$ count $7.65>Q$ table 3.15. 5) There is a difference in the ability of fundamental movement skills of children between groups of children who have a lean/obese BMI given SPRP with children who are given conventional learning strategies with a $Q$ count value of 4.25> Qtable 3.15.
\end{abstract}

\section{Keywords-BMI, Fundamental Motor Skill}

\section{INTRODUCTION}

Education becomes something that is really needed where through education can at least change one's thinking patterns to be more open and insightful besides that education is also an arena where each individual competes with each other showing their best ability to achieve the goals they want. Unknowingly education leads us to always ready to face challenges according to the times that are getting higher and higher. In Indonesia education is divided into three, which are: (1) Formal Education, (2)

Non-Formal Education, and (3) Informal Education. Formal education is organized in a structured and tiered such as Early Childhood Education, Elementary Schools, Middle Schools, and Colleges.
Early Childhood Education is the early education of children starting to get to know, do social interaction through play movements and explore the surrounding environment. Therefore, the development of a child's basic movement skills during Early Childhood Education is very important to note. This was stated in the Basic Framework and Curriculum Structure book 203 Early Childhood Education in the description of the standard level of developmental achievement (STPP) in point (b) outlined about motor physics (pp.30-31) [1] including:

1) Rough Motor: has the ability to coordinate body, flexible, balanced, and agile and follows the rules.

2) Soft Motor: has the ability to use tools to explore and express themselves in various forms.

3) Health and Safety Behavior: having a weight, height, head circumference according to age and having the ability to behave clean, healthy, and care for their safety.

In other words in the 2013 curriculum Indonesian education has given children the opportunity to actively engage in physical activities from an early age. However, this is contrary to what put forward by the World Health Organization (WHO). According to WHO, in Indonesia found the phenomenon of obesity which has reached $25.4 \%$ of the population of around 260 million people with the largest percentage found in children aged 0-14 years. This is due to various factors, one of which is the lack of opportunities for children to do physical activities [2].

Basic motion skills are the basis of all physical activity of children which basically involves the strength of the muscles of the hands and feet. According to what is explained that "Basic motion is a skill that involves the cerebrum, muscle strength involving the arms and legs used to achieve an exercise or movement goals, such as throwing a ball, jumping, or jumping through the motion of water, or maintaining balance. Basic motion is the basis for learning and developing various technical skills in sports and physical activity for life "[1].

It is said that "Basic movement skills are movement skills that involve large muscle skills, body muscle strength, arms and legs used to achieve exercise or movement goals. Like spinning a ball to a friend or jumping over a puddle" [3] Clark (1994). Basic motion skills are the ABCs of motion. Children cannot automatically obtain a degree of mastery of perfect appearance in basic motion skills. Like many skills, they must be taught [4]. 
According to Thelen and Smith"Physical growth and a child's history of movement experiences play a fundamental role in influencing shifts in patterns of movement. If deficits in gross motor development are not identified and remediated, the child may experience lifelong problems with motor skills", which means "The physical development and history of a child in the experience of motion are the main abilities that affect movement patterns. If deficiencies in gross motor development are not identified and corrected, children may experience eternal problems with motor skills "[5].

Based on observations made by researchers in several kindergartens / kindergartens in West Sumatra, it can be concluded that many of the motion activities that are applied by most kindergarten teachers to children with limited understanding. Many kindergarten teachers do not really understand the importance of basic physical abilities for children and their influence on the development of children's cognitive and psychomotor abilities through movement activities. This is due to many factors, such as (1) the lack of kindergarten teacher information about basic movement skills due to literacy sources about basic motion mostly from outside Indonesia who speak English so that it makes it difficult for kindergarten teachers the majority do not have active English language skills; (2) openness in welcoming new teaching methods that are more creative and innovative in delivering learning material; (3) lack of attention from related parties in conducting training or seminars on basic movement skills for children; (4) there are no forms of learning as operational guidelines for kindergarten teachers.

Obstacles that experienced by kindergarten teachers greatly affect the learning process which can worsen the condition of the development of children's basic mobility at an early age. This can be seen from the number of teachers and children doing it on the wrong movements and poorly controlled motion activities. Conditions like this are certainly something that is very dangerous and should be an important concern because if it is done continuously and become a habit, later the child will have difficulty in repairing the movement. And if the child has limited motion at the age of play, then it is worried that the child will have a little experience of the motion that he will show in the future.

Education in kindergarten must be covered by the activeness of children in playing, singing, and doing activities / work, because these three things will hone the brain, intelligence, emotions, and physical skills performed cheerfully, freely, and without burden. According to Helms and Turner states playing is a way for children to express the results of their thoughts, feelings, and ways to explore the world of their environment, including helping establish social relations between children and children [6]. Thus, kindergarten teachers are required to be able to give learning situations that run naturally and are loved by kindergarten children without any pressure and feeling forced to the game strategy chosen. These conditions will make it easier to develop children's basic mobility abilities. While Conventional Learning is one of learning that only focuses on lecture learning methods.
Bower (2002) stated that conventional learning emphasizes content recitation, without giving students sufficient time to reflect on the material presented, link it with prior knowledge, or apply it to real life situations. Conventional learning has the characteristics of: (1) Teacher-centered learning, (2) passive learning occurs, (3) lack of interaction between students, (4) no cooperative groups, and (5) assessment is sporadic [7].

Based on some of the opinions that have been described above, researchers feel the need to conduct research to reveal the extent of basic object control skills of children in TK Pembina Kota Padang Panjang Panjang. As well as BMI (Body Mass Indexs) at TK Pembina Kota Padang Panjang. And to measure the learning strategy of a series of games whether it can improve basic movement skills in early childhood

\section{ABILITY OF OBJECT CONTROL AND LEARNING STRATEGY}

\section{A. The Ability of Object Control}

Basic motion skills are the ABCs of motion. Children cannot automatically obtain a degree of mastery of perfect appearance in basic motion skills. Like many other skills, they must be taught [4]. A child who has basic movement skills will also have the opportunity to develop his skills well in other fields, especially in sports. During the early years of elementary school, a child's gross motor skills serve a significant rule / regulation function in influencing how his peers regard the child [5].

Human development consists of several periods as follows: a) the period of pre-birth (penatal period), ie the period of conception to birth; b) infancy from birth to 18 or 24 months; c) early childhood (early childhood) or also known as "preschool" which is the end of infancy until the age of 5 or 6 years; d) the middle and late childhood or primary school period ", namely the age of children aged 6 to 11 years; e) adolescence (adolescence), is a transition period from childhood to the beginning of adulthood where children aged 10 to 12 years and ends at the age of 18 to 22 years; f) early adulthood, beginning in the late teens or early 20 years and ending at 30 years; g) the middle adulthood starts from about 35 to 45 years to 60 years; and h) late adulthood begins at the age of 60 or 70 years and ends in death. Next to be discussed in this study are children who are in elementary school or children aged 6 to 12 years [8]. The elements contained in motor skills are: a) Strength, b) Coordination, c) Speed, d) Balance and e) Agility [6]. Basic motion skills are grouped into three parts, namely: a) locomotor skills, b) balance skills, and c) manipulative skills [1]. Object control places more emphasis on gross motor skills that show efficient throwing, hitting and catching movements [5]

\section{B. Learning Strategies}

In simple language learning strategies are strategies to teach students towards the achievement of instructional goals [9]. Play is one of the learning strategies for young children that children can participate in a fun way. Through play children are invited to explore 
(exploratory), discover, and utilize different things around them [10]. Montessori said that the game as an "inner needs" for every child because play is able to please the heart, improve skills and improve children's development. This concept of play is what he later refers to as learning while playing [10].

Conventional strategy is a learning strategy that is commonly used by teachers in daily life at school. Usually this conventional learning strategy is more teacher center oriented, which means it is centered on the teacher. Conventional learning is one of learning that only focuses on lecture learning methods. Bower (2002) stated that conventional learning emphasizes content recitation, without giving students sufficient time to reflect on the material presented, link it with prior knowledge, or apply it to real life situations [7].

\section{Body Mass Index}

Body Mass Index (BMI) or also called Body Mass Index (BMI) is the most commonly used and practical indicator for measuring the level of overweight population and obesity in adults [11]. Body Mass Index (BMI) is a technique to calculate body weight index, so we can know the category of our body whether classified as thin, normal and obese (overweight). Body Mass Index (BMI) can be used to control body weight so that it can reach normal weight according to height. When applied to individuals, only one of several assessments is used to determine risk for weight-related illnesses (underweight, overweight, or obese). [11].

\section{THE DATA ACQUISITION SETUP}

The instrument used to obtain data on BMI of TK Panjang Pembina Kindergarten students was to measure height using a meter with a centimeters scale and body weight using a digital scale with a note of two digits behind the comma. The use of digital scales is considered more biased to provide an exact calculation of the weight. Whereas the ability to control the child's obej is obtained through the Test of Gross Motor Development-2 (TGMD2) which consists of strike, catch, dribble, kick, throw and roll. Each test item has criteria that must be met by the child in the assessment. For each movement that matches each criterion on each skill will be given a value of 1 while those who do not match are given a value of 0 . The ability of this control object is based on a video that has been recorded using a handycame while the research is in progress. All children were asked to do every ability of the control object 3 times. The first try is considered an exercise. The second and third experiments will only be an assessment in the study.

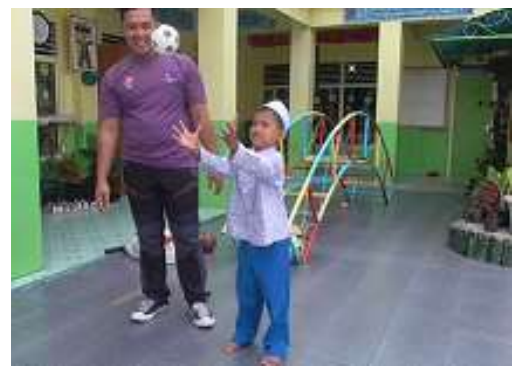

Picture 1. Illustration of catching a ball

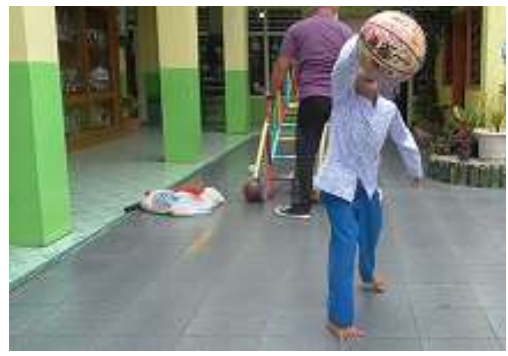

Picture 2. Illustration of reflecting a basketball

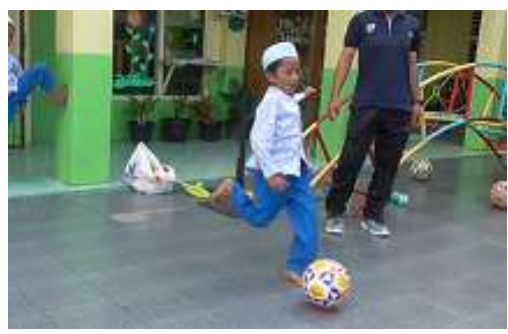

Picture 3. Illustration of kicking a bal

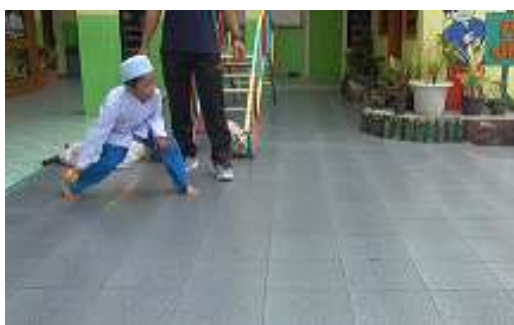

Picyure 4. Ilustrasi Illustration of under arm roll

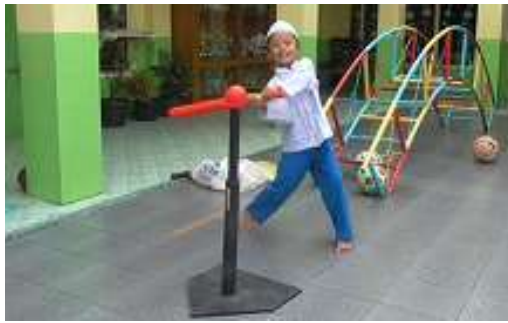

Picture 5. Illustration of hitting a ball

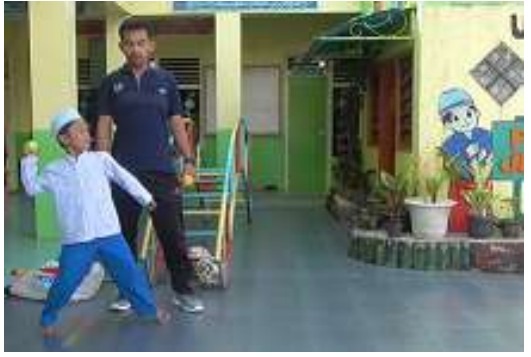

Picture 6. Illustration of throwing a ball

\section{THE DATASET}

Kindergarten students' Object Control ability data in Padang Panjang City were taken in 2 repetitions for all children for each skill tested. Data from the test is stored in video format. The grading of the level of development of this locomotor ability is based on the INDO-SKIP Training sheet. Then for the child's equilibrium data obtained with 1 trial for each movement and this data is stored in the form 
of a test sheet. This test is given to children aged 5 to 6 years. The number of students involved was 42 consisting of 24 women and 18 men.

\section{CONCLUSIONS}

The Object Control ability data of kindergarten students in Padang Panjang City uses instruments that have been standardized and are used by many countries in the world. This study involved 42 PAUD students. The data obtained in this study has a pretty good quality because it uses a valid instrument and all the criteria for locomotor ability skills are judged to have been coded by experts. In the future, we will try to apply a learning model that is in line with the PAUD curriculum in Indonesia.

\section{REFERENCES}

[1] B, Syahrial. "Merancang Pembelajaran Gerak Dasar Anak". Padang; UNP Press. 2015.pp.30-45.
[2] World Health Organization (WHO). "Technical Report Series 894; Obesity, Preventing and Managing the Global Epidemic". Geneva: World Health Organization. 2004.pp.55-57.

[3] Clark JE, Metcalfe JS. "The mountain of motor development. In: Clark JE, Humprehy JH, editors. Motor development: research and reviews". Vol. 2. Reston (VA): National As-sociation of Sport \&Physical Education, 2002: 163-90.

[4] Goodway,J. D.,Robinson, L. E.,\& Crowe, H (under review). "Developmental Delay in Fundamental Motor Skill Development of ethnically Diverse and Disadvantaged Prescoolers", Submitted to Journal Research Quarterly for Exercise and Sport. 2006.

[5] Ulrich, D. A. "The Test of Gross Motor Development (Second ed)". Austin: TX Pro-ed. 2000.pp.12-23.

[6] Gusril. "Perkembangan Motorik Pada Masa Anak-Anak". Padang. UNP Press. 2015.pp.10-18.

[7] Santrok, John W. "Life Span Development: Perkembangan Masa Hidup Edisi V Jilid 1 dan 2 (Diterjemahkan oleh Achmad Chusairi dan Juda Damanik)". Jakarta: Erlangga. 2002.pp.10-21.

[8] Nurmaidah. "Startegi Pembelajaran Anak Usia Dini". Jurnal Al Afkar Vol III Nomor.1. 2015.pp.55-67.

[9] Suyadi \& Maulidya Ulfah. "Konsep Dasar PAUD”. Bandung: Remaja Rosdakarya. 2013.pp.11-14.

[10] S, Soegondo. P, Soewondo. L.Subekti "Penatalaksanaan Diabetes Melitus Terpadu”. Jakarta: FKUI. 2011.pp.23-44.

[11] Alhamda, Syukra. "Buku Ajar Ilmu Kesehatan Masyarakat (IKM)". Yogyakarta: Deeplish. 2015.pp.11-17. 